\title{
Cultivating Effective Practices in Government ANd Policy-Making: SUMMARY OF AN INTERVIEW WITH Virginia Governor Mark R. WarNer
}

On March 31, 2005, the Editor-in-Chief of Policy Perspectives had the opportunity to speak with Governor Mark R. Warner of Virginia about his tenure as the state's chief executive. The conversation focused on Virginia's successes in government management, the relationship between federal and state-level policy, and the responsibilities of professionals in the field of public policy.

Policy Perspectrves: The Government Performance Project recently completed an assessment of the quality of government management in each of the 50 U.S. states. ${ }^{1}$ Because Virginia received the highest grade given, we are interested in hearing about what you are doing. Specifically, what do you feel are the major factors contributing to Virginia's impressive performance on the recent assessment?

Governor WARNER: When I took over as Governor of Virginia in 2002, the state was in a fiscal melt-down: departments did not have appropriate financial

MARK R. WARNER was inaugurated as governor of Virginia in January of 2002. Since then, he has worked to eliminate a \$6-billion revenue shortfall; launched comprehensive state government reforms; and implemented innovative, low-cost programs to increase student achievement and accountability in public schools through his Education for a Lifetime initiative. Warner also has worked to make Virginia government a leader in technology and provide opportunities for small businesses and those owned by women and minorities. Governor Warner assembled a bipartisan coalition to win approval from the 2004 Virginia General Assembly for one of the nation's most ambitious tax reform proposals, allowing the Commonwealth to make historic investments in $K-12$ and post-secondary education, law enforcement and health care while preserving the state's reputation for fiscal integrity.

Warner served as chairman of the Southern oversight; our largest department, the Department of Transportation (DOT), was overly politicized due to short-sighted fiscal policies; and we were facing a substantial budgetary shortfall. Much of this was due to structural fiscal imbalance created by faulty predictions about economic growth and resulting overcommitment of funds on the part of the state government in the past.

During my first two years in office, we worked to address this imbalance in a number of ways. We sought to bring business practices to government. We developed initiatives that allowed us to leverage

Governors'Association, states' co-chairman of the Appalachian Regional Commission, and chairman of the Education Commission of the States, a national nonpartisan policy organization. Warner is currently the chairman of the National Governors Association.

Warner was born in Indianapolis, Indiana. He was the first in his family to graduate from college, completing his degree at The George Washington University in 1977 and graduating from Harvard Law School in 1980. He is a founding partner of Columbia Capital Corporation and helped create more than 70 telecommunications and information technology companies. His regional venture capital funds have helped small business start-ups in underserved areas of Virginia and his ongoing philanthropic endeavors help families find care for seniors, help minority college students find jobs in the tech industry, and helpbridge the digital divide through computer instruction in houses of worship. 
purchasing power, consolidate our information technology resources, and revamp our approach to the state real estate portfolio. Generally, we worked to change our approach to governance to allow us to focus on long-term savings.

Specifically, we were able to de-politicize the Department of Transportation by bringing business professionals into the agency and working to be straight with the public. In the past, DOT had not done a good job of communicating with and meeting the expectations of the public and had promised programs that it could not deliver. Since I took office, we have established a system of operations at DOT that is more transparent and accessible to the public, which has resulted in greater public support of the department.

Beginning in 2004, even with a recovering economy, we still had a structural budget deficit. In order to address our fiscal problems, we launched a major bi-partisan tax teform effort intended to allow the state to taise sufficient revenues to fund government programs. We did not expand programs, but we were able to do what true fiscal conservatives should do, which is raise revenue to pay the bills and meet the commitments of the government. As a result, in 2004, the state successfully reaffirmed its Triple A bond rating. One of the major factors driving our success was the fact that we were able to show Virginians that their tax dollars were being well spent on investments in education and economic growth. As a result, we now have the $2^{\text {nd }}$ fastest growing economy in the country and our state remains attractive to companies, as fiscal order at the state level provides a healthy environment for business.

Policy Perspectrves: In shaping Virginia's recent successes, how important was the ability to balance established management strategies with innovative and original approaches?

GOVERNOR WARNER: Innovation is essential. Government tends to be resistant to change and is often the least innovative part of society. The need to develop new approaches to government operations is an important part of Virginia's recent fiscal success. For example, the Virginia Information Technologies Agency (VITA) consolidated IT services and purchasing practices spread throughout 93 agencies into a single body. We also work to be innovative in how we look at the delivery of services by promoting public-private solutions in areas such as transportation in which these partnerships may allow us to meet the needs of the public more effectively. Public-private collaboration is an innovative approach to the provision of government services. Finally, we have introduced innovative practices aimed at increasing student performance and accountability in Virginia public schools.

One area in which our state continues to struggle to find effective, innovative approaches is the provision of health care, both from a quality of care and finance standpoint. We are working hard to find new ways to meet the demands of the public but this is certainly an area of policy in which we have much room to grow.

Policy Perspectrves: As chairman of the National Governors Association (NGA), you have had the opportunity to champion a variety of new state-level initiatives aimed at improving states' abilities to meet the needs of their citizens. It seems clear that the feasibility and effectiveness of these efforts at the state level often is influenced by related federal policy. How would you describe the current relationship between federal and state education policy? Specifically, what is the relationship of the Redesigning the American High School initiative that you launched in the NGA to the federal No Child Left Behind Act (NCL,B)?

GOVERNOR WARNER: No Child Left Behind has worthy and lofty goals. However, implementation has been amiss. Specifically, implementation of NCLB requirements in Virginia has been complicated due to the fact that the legislation required states like outs, which were further along the path in terms of raising standards and improving accountability in education, to reinvent the wheel.

As chairman of the National Governots Association, I decided to take on the issue of high school reform because this is something that state governments can effectively implement. I am glad to see that the president's 2006 budget proposes funding to enhance the quality of high school education as well. However, in a general sense, I think that there currently is an uneasy balance between federal and state education policy. 
Right now, I am trying to rally the NGA to push for reform of federal education policy because I think that this year offers great opportunities to make significant changes, as Head Start and the Higher Education Act are up for reauthorization, and changes to NCLB may also come up for consideration. I believe that this year provides us with a great opportunity to align federal and state-level education policy goals and modify funding formulas to fit together better. Taking this opportunity will allow us to avoid a mismatch between federal initiatives and state efforts and avoid creating more unfunded mandates to be met by the states.

Ultimately, the states need the federal government to come prepared as a true partner, willing to be flexible and collaborative. Additionally, we need the federal government to do a better job of learning from the states' experiences and recognizing that some states are already ahead of the curve and should not be required to go back to the beginning to meet the requirements of federal legislation. I am hopeful and confident that the recently appointed Secretary of Education, Margaret Spellings, is going to be more flexible in her approach to federal education policy.

Policy Perspectrves: Many of our readers are in the early stages of their professional careets in public policy. As a leader in the field, what do you see as the most important responsibilities of members of the policy community, including policy analysts, politicians, and community advocates, when it comes to the process of making public policy?

GOVERNOR WARNER: One of the most important responsibilities of members of the policy community is to try to resist the urge to fall into ideological camps on either end of the political spectrum. We need policy analysts who are able to provide elected officials with what they need: good, honest, data-driven research and information.

I think it is great that many young people are choosing to pursue careers in policy rather than business or law at a time when it is popular to demonize government. We need good people in policy and we need them to hold on to the kinds of innovative ideas and idealistic motivations that get them into the field in the first place. It is important to stay true to that innovation and idealism.

Additionally, it is important to stay true to the goal of serving as a neutral broker of information to elected officials because members of the policy community face a lot of adrocates and what leaders need from policy analysts is that neutral view that has the interests of the state and community at heart.

\section{Notes}

${ }^{1}$ This project evaluated state management practices in four categories: money, people, infrastructure, and information. For more information on the Government Performance Project and the "Grading the States 2005" assessment please refer to: http:// results.gpponline.org. 
